\title{
LANDFILL SITE SELECTION FOR MUNICIPAL SOLID WASTE BY USING AHP METHOD IN GIS ENVIRONMENT: WASTE MANAGEMENT DECISION-SUPPORT IN SICILY (ITALY)
}

\author{
Luciana Randazzo 1,*, Antonio Cusumano ${ }^{2}$, Giuseppe Oliveri 2, Pietro Di Stefano 2 , \\ Pietro Renda ${ }^{2}$, Marcella Perricone ${ }^{2}$ and Giuseppe Zarcone ${ }^{2}$ \\ ${ }^{1}$ Dipartimento di Biologia, Ecologia e Scienze della Terra (DiBEST) - University of Calabria, via Pietro Bucci, Cubo12b, 87036 \\ Arcavacata di Rende (CS), Italy \\ ${ }^{2}$ Dipartimento di Scienze della Terra e del Mare (DiSTeM) - University of Palermo, via Archirafi 22, 90123 Palermo, Italy
}

Article Info:
Received:
4 March 2018
Revised:
27 April 2018
Accepted:
30 May 2018
Available online:
30 June 2018
Keywords:
Municipal solid waste
Landfill
Analytical hierarchy process
Geographic information system
Sicily

Article Info:

Received:

Revised:

Available online:

Municipal solid waste

Landfill

Sicily

\begin{abstract}
The goal of this work was to test a methodology, based on multi-criteria analysis and geographic information systems, aimed at identifying areas potentially suitable to host landfills for Municipal Solid Waste (MSW). Although the above-mentioned methodology was applied to three different areas (Western, South-western and Eastern) of Sicily, in this paper, we present the results of the western sector. The first step consisted of the division of the study area in excluded and potentially suitable sites, on the basis of the Italian current legislation. The suitable sites were subsequently re-evaluated based on additional criteria in order to choose the most suitable ones. This second step consisted of a multi-criteria analysis based on a scores and weights system. The Analytic Hierarchy Process (AHP) was applied to estimate the relative importance weights of the evaluation criteria. The suitability for landfill siting was finally evaluated with the aid of a simple additive weighting method. The resulting land suitability was reported on a scale of 0 to 10 , respectively, from the least suitable to the most suitable sites. In order to reveal the most suitable sites, to provide a ranking and, consequently, a quick selection, a spatial clustering process was carried out. In relation to the data obtained, several suitable areas to host sites for MSW landfill in Western Sicily were identified. The application of multi-criteria analysis, together with the use of geographic information systems, provided a powerful tool for the identification of the most suitable site among those identified.
\end{abstract}

\section{INTRODUCTION}

Waste is an important cause of environmental load and a marker of dissipating resources. Proper waste disposal, without compromising natural reserves and environmental quality, has become an absolute necessity to avoid environmental and public health risks (Pires et al., 2010) and is one of the greatest tasks of our times. Landfill is the most popular method of waste disposal currently being used; however, it is not the only method. In fact, an integrated waste management system comprising recycling of materials and, to a lesser extent, incineration or combustion, should be the preferred method (Sakai et al., 1996; Seadon, 2006). Today, many areas and administration departments are re-evaluating the use of landfills because of the lack of available space and the presence of methane and other landfill gases, which lead to numerous contamination problems.
In Sicily, Italy, waste management involves a series of problems, such as difficulties in monitoring and verifying the efficiency of landfills, low recycling levels (less than $10 \%$ in 2009), reduced waste capacity of authorised landfills and delays in the realization of the pre-treatment plants to reduce waste volume.

Therefore, this paper aims to test a methodology based on the application of Analytic Hierarchy Process (AHP) combined with Geographic Information System (GIS) in order to obtain a map of areas suitable for landfill establishment. This methodology has been applied to an area within the Western sector of Sicily in order to identify suitable landfill sites for Municipal Solid Waste (MSW) and to ensure the effectiveness of the proposed method. The use of special tools, such as GIS software, has enabled us to quickly manage and efficiently process large amounts of input data within a specific geodatabase (geology, geomorphology, hydrology, meteorological and climatic aspects, 
constraints imposed by regulatory and legislation both national and regional, etc.). Firstly, this processing was based on a preliminary division of the Sicilian territory carried out within the frame of the SIGLOD Project (Sistema Intelligente di Supporto alla Gestione e alla Localizzazione delle Discariche di Rifiuti), an intelligent support system for the management and localisation of landfills and waste management plants, by researchers involved in the project. It will be an applied and integrated technological infrastructure that will allow public organisations to recover technological efficiency and competitiveness through the use of satellite data. This first subdivision identified unsuitable areas (in red colour), low suitable areas (in blue colour) and suitable areas (in white colour) for establishment of MSW landfills (Perricone et al., 2016), starting from constraints imposed by current national and regional legislation (Figure 1a), that follow the requirements of Directive 1999/31/ EC on the landfill of waste. Subsequently, the suitable areas previously identified were analysed and reconsidered on the basis of more detailed factors in order to select the most suitable areas. Although this procedure has been applied to three different sectors of Sicily (Western, Eastern and Southern sectors), which showed a higher proportion of potentially suitable areas, this paper will show results pertaining the Western sector of Sicily (Figure 1b).

\section{DATA AND METHODS}

\subsection{Study area}

The examined area is located in the Western sector of Sicily between $12^{\circ} 51^{\prime} 00^{\prime \prime}$ E and $13^{\circ} 19^{\prime} 00^{\prime \prime}$ E and $37^{\circ} 59^{\prime} 00^{\prime \prime} \mathrm{N}$ and $37^{\circ} 47^{\prime} 30^{\prime \prime} \mathrm{N}$. It includes twenty municipalities (Alcamo, Calatafımi, Castellamare del Golfo, Gibellina, Poggioreale, Salaparuta, Salemi, Santa Ninfa, Vita, Bisacquino, Camporeale, Contessa Entellina, Corleone, Monreale, Partinico, Piana degli Albanesi, Roccamena, San Cipirello, San Giuseppe Jato, Santa Cristina Gela) falling within the provinces of Trapani and Palermo (Figure 1b). It covers an area of $1,160 \mathrm{~km}^{2}$, with an average elevation of 254 meters above sea level. The study area is predominantly hilly, which is typical of the Sicilian hinterland, and is mainly characterised by sandy and clay deposits with some limestone outcroppings. Agriculture is the predominant land use within the region. The closest main towns include Palermo, Tra- pani, Mazara del Vallo, Marsala and Castelvetrano; the area had a population of 205,812 in 2011 (ISTAT 2011).

\subsection{Methodology}

Recently, both in Italy and globally, the methodology adopted for the identification of areas potentially suitable to receive municipal solid waste (landfills) has been generally based on hierarchical analytical approaches associated with Geographical Information Systems (GIS) in order to examine various criteria, including geology and hydrogeology, land use, land slope, distance from roads, residential areas, protected areas and wind direction (Dörhöfer and Siebert, 1998; Kontos et al., 2005; Chang et al., 2008; Sumathi et al., 2008; Zamorano et al., 2008; Sharifi et al., 2009; Carone and Sansò, 2010; Moeinaddini et al., 2010; Nas et al., 2010; Sener et al., 2010; Gbanie et al., 2013). Each criterion is evaluated according to a system based on scores and weights and mapped using GIS techniques. The data collected are grouped into classes that express the greater or lesser suitability of an area.

For this study, we selected eight criteria for the evaluation of landfill suitability. A meso-scale method provided the identification of new factors or the use of a greater detail for those factors previously used in the phase of macro-scale localisation. The factors were grouped according to economic or environmental importance and each factor was assigned values from five to six classes with scores between 0 and 10 .

Subsequently, a "weight" was then assigned to each factor by means of a hierarchical analysis that establishes a priority scale within the factors.

The suitability of an area was then assessed by the use of a simple system of weighted summation (SAW, Simple Additive Weighting). This system is widely used for the calculation of final values in issues using multiple criteria. The mathematical formulation of this system is described by the following equation (Yoon and Hwang, 1995):

$\mathrm{V} i=\sum_{j=1}^{n} W j v i j$

where $\mathrm{V} i$ is the suitability index for the area $i, W j$ is the relative importance of the weight given to the criterion $j$, vij is the priority value of the area $i$ with respect to the criterion $j, n$ is the total number of criteria.

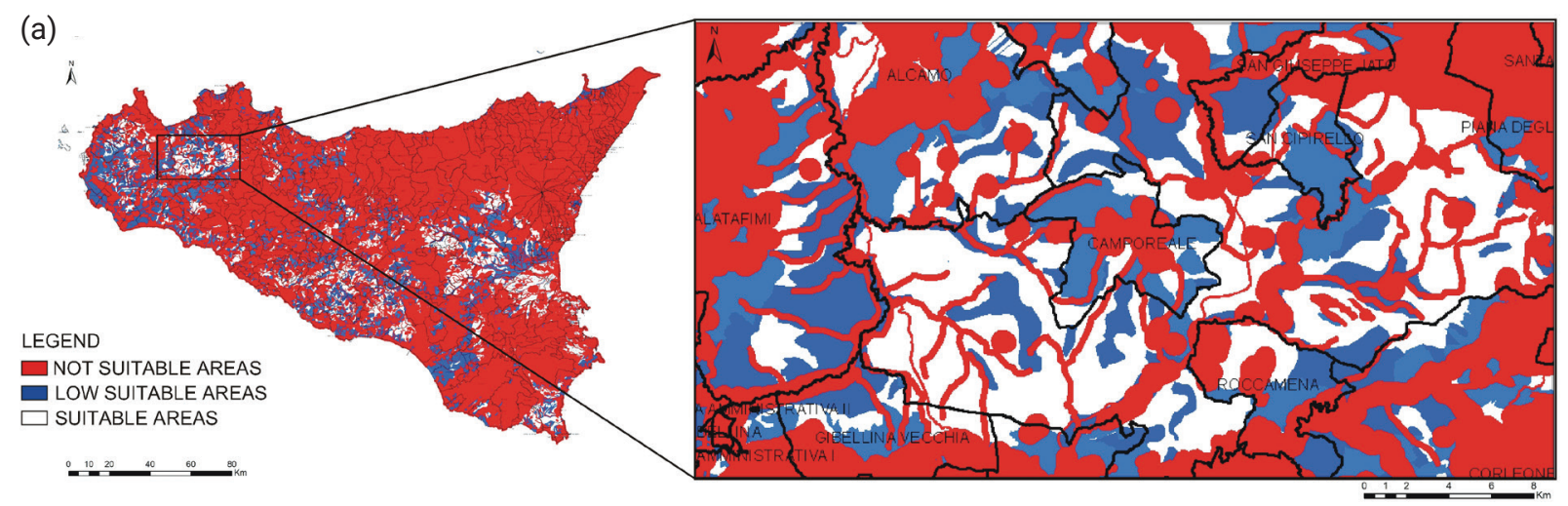

(b)

FIGURE 1: (a) Preliminary division of the Sicilian territory from constraints imposed by current national and regional legislation (Perricone et al., 2016); (b) the study area in the Western sector of Sicily. 
The end result of this methodology was the evaluation of the territory on the basis of suitability indices. In this study, the used scale for such indices ranged from 0 (less suitable area) to 10 (most suitable area).

In this work, we applied a multi-criteria analysis for decision-making purposes (Multi Criteria Decision Analysis, MCDA). This method is directed at supporting the decision maker when he is working with numerous and disputing evaluations, allowing him to obtain an agreement solution.

There are several methods for multi-criteria analysis and MCDA is now used in various application fields, such as finance, planning, telecommunications and ecology.

Among the most commonly used method of MCDA, the so-called AHP (Analytical Hierarchy Process) method was applied in this work. The AHP method mainly allows to assign a priority to a number of decision alternatives and/or to relate criteria characterised by qualitative and quantitative assessments (often not directly comparable), combining multidimensional measures into a single scale of priorities (Saaty, 1980). AHP, in short, is a method to derive ratio scales from paired comparisons (Siddiqui et al., 1996; Mandylas et al., 1998; Balis et al., 1998; Kontos and Halvadakis, 2002; Kontos et al., 2003).

The comparison was performed using a nine-point scale that includes: $[9,8,7, \ldots, 1 / 7,1 / 8,1 / 9]$, where 9 means extreme preference, 7 means very strong preference, 5 means strong preference, and so on down to 1 , which means no preference (Table 1). This pair-wise comparison allowed for an independent evaluation of the contribution of each factor, thereby simplifying the decision making process. The pair-wise comparisons of various criteria were organised into a square matrix (Table 2).

The diagonal elements of the matrix were: 1 . The principal eigenvalue and the corresponding normalised right eigenvector of the comparison matrix gave the relative importance of the criteria being compared. The elements of the normalised eigenvector were weighted with respect to the criteria or sub-criteria and rated with respect to the alternatives (Bhushan and Rai, 2004). The consistency of the matrix of order $n$ was then evaluated. If this consistency index failed to reach a threshold level, then the answers to comparisons were re-examined. The consistency index, $\mathrm{Cl}$, was calculated as:

$\mathrm{CI}=\frac{\lambda_{\max }-\mathrm{n}}{\mathrm{n}-1}$

where $\mathrm{CI}$ is the consistency index, $\lambda_{\max }$ is the largest or principal eigenvalue of the matrix, and $n$ is the order of the matrix. This CI can be compared to that of a random matrix, the Random Consistency Index (RI), such that the ratio, $\mathrm{Cl} / \mathrm{RI}$, is the consistency ratio, $\mathrm{CR}$. As a general rule, $\mathrm{CR} \leq 0.1$ should be maintained for the matrix to be consistent. For this study, RI is equal to 1.41 and calculated $\lambda_{\max }$ is equal to 8.599 , producing a $\mathrm{Cl}$ of 0.085 . The consistency ratio $\mathrm{CR}$ was 0.060 ; thus indicating that a consistent matrix was formed. However, there may be a different judgment regarding the relative importance of the criteria when these

TABLE 1: The comparison scale in AHP (Saaty 1980).

\begin{tabular}{|c|c|}
\hline \multicolumn{2}{|l|}{ Intensity of importance } \\
\hline 1 & Equal importance \\
\hline 3 & Weak importance of one over another \\
\hline 5 & Essential or strong importance \\
\hline 7 & Demonstrated importance \\
\hline 9 & Absolute importance \\
\hline $2,4,6,8$ & Intermediate values between the two adjacent judgments \\
\hline Reciprocals of above nonzero & $\begin{array}{l}\text { If activity } i \text { has one of the above nonzero numbers assigned to it when compared with activity } j \text {, then } j \\
\text { has the reciprocal value when compared with } i\end{array}$ \\
\hline
\end{tabular}

TABLE 2: Square matrix of the pair-wise comparisons of various criteria.

\begin{tabular}{|c|c|c|c|c|c|c|c|c|c|}
\hline Criteria & $\begin{array}{c}\text { Rock } \\
\text { Permeability }\end{array}$ & $\begin{array}{l}\text { Average } \\
\text { annual } \\
\text { rainfall }\end{array}$ & $\begin{array}{c}\text { Seismic } \\
\text { activity } \\
\text { risk }\end{array}$ & $\begin{array}{c}\text { Distance } \\
\text { from } \\
\text { settlements }\end{array}$ & $\begin{array}{l}\text { Land } \\
\text { slope }\end{array}$ & $\begin{array}{l}\text { Land } \\
\text { use }\end{array}$ & $\begin{array}{l}\text { Distance } \\
\text { from roads }\end{array}$ & $\begin{array}{l}\text { Distances } \\
\text { from surface } \\
\text { waters }\end{array}$ & $\begin{array}{c}\text { Factor } \\
\text { weights } \\
(\%)\end{array}$ \\
\hline Rock permeability & 1.00 & 5.00 & 5.00 & 7.00 & 1.00 & 3.00 & 9.00 & 3.00 & 0.299 \\
\hline $\begin{array}{l}\text { Average annual } \\
\text { rainfall }\end{array}$ & $1 / 5$ & 1.00 & 1.00 & 3.00 & $1 / 5$ & $1 / 3$ & 7.00 & $1 / 3$ & 0.058 \\
\hline $\begin{array}{l}\text { Peak ground } \\
\text { acceleration }\end{array}$ & $1 / 5$ & 1.00 & 1.00 & 3.00 & $1 / 5$ & $1 / 3$ & 7.00 & $1 / 3$ & 0.058 \\
\hline $\begin{array}{l}\text { Distance from } \\
\text { settlements }\end{array}$ & $1 / 7$ & $1 / 3$ & $1 / 3$ & 1.00 & $1 / 7$ & $1 / 5$ & 3.00 & $1 / 5$ & 0.035 \\
\hline Land slope & 1.00 & 5.00 & 5.00 & 7.00 & 1.00 & 3.00 & 9.00 & 3.00 & 0.299 \\
\hline Land use & $1 / 3$ & 3.00 & 3.00 & 5.00 & $1 / 3$ & 1.00 & 7.00 & 1.00 & 0.113 \\
\hline Distance from roads & $1 / 9$ & $1 / 7$ & $1 / 7$ & $1 / 3$ & $1 / 9$ & $1 / 7$ & 1.00 & $1 / 7$ & 0.025 \\
\hline $\begin{array}{l}\text { Distance from } \\
\text { surface waters }\end{array}$ & $1 / 3$ & 3.00 & 3.00 & 5.00 & $1 / 3$ & 1.00 & 7.00 & 1.00 & 0.113 \\
\hline Total & 3.32 & 18.48 & 18.48 & 31.33 & 3.32 & 9.01 & 50.00 & 9.01 & 1.00 \\
\hline
\end{tabular}


are compared in pairs. The decision process in multi-criterion problems is a subjective process, strongly linked to the decision maker. In complex problems, such as the identification of landfill sites, it is logical to expect people involved can have different opinions.

\subsection{Criteria description and application}

The assessment criteria used in this work were divided into two main categories: environmental criteria and economic criteria. To each factor, we assigned 5 to 6 classes of values, with a score between 0 and 10 (Table 3 ). Higher scores are representative of more favourable conditions of the location.

The environmental criteria included the five factors rock permeability, distance from settlements, average annual rainfall, peak ground acceleration and distance from surface water, as shown in Table 3.

The economic criteria included factors that affect the construction and the operations management of a landfill. The parameters here considered were land slopes, distance from roads and land use.

\subsubsection{Environmental criteria}

Among the environmental issues, great importance is attributed to the proximity of a landfill site from inhabited population centres. In fact, a landfill site located near an urban settlement poses many environmental problems, not least those related to the presence of unpleasant odours. Therefore, the direct distance of the examined sites from urban areas was taken into account, assigning the highest score with the increasing of this distance. In particular, in this work, we proposed bands at a distance gradually increasing and with an interval of $1,000 \mathrm{~m}$ (Figure 2). For distances less than the legal limits $(500 \mathrm{~m})$, we assigned a score of 0 .The second parameter considered here is the rock permeability. National and regional law identifies the presence of exclusionary, penalising and preferential factors according to the coefficient of permeability and to primary and secondary porosity. During the application of the meso-scale method, the permeability factor has been re-considered and applied in order to add a greater level of detail. Rock classification on the basis of the permeability coefficient $\mathrm{K}$ is often arbitrary and subjective, mainly because of the wide range of $K$ values of rocks and unconsolidated materials. However, a generalisation can be made in order to classify the study area into zones of permeability using, commonly accepted classification schemes from the literature (Colombo and Colleselli, 1994) and integrated with the data of permeability obtained from PAI (Piano di Assetto Idrogeologico) of Sicily for the types of terrains falling in the examined zones. In the present work, five classes were identified (Table 3), assigning a weight from 0 to 10 to the different degrees and permeability values identified (Figure 3).

Terrains with high permeability are considered unsuitable for establishing a landfill and were consequently attributed the lower value (0). In contrast, optimal sites are those with extremely low permeability or impermeable sites. A score of ten was attributed to the latter sites.

The third criterion, i.e. the average annual rainfall, was taken into account in order to assess the impact of rainfall
TABLE 3: Square matrix of the pair-wise comparisons of various criteria.

\begin{tabular}{|c|c|c|}
\hline Main criteria & Classes & Scores \\
\hline \multicolumn{3}{|l|}{ Environmental criteria } \\
\hline \multirow{5}{*}{ Rock permeability } & High $\left(K>10^{-3}\right)$ & 0 \\
\hline & Medium $\left(10-3<K<10^{-5}\right)$ & 3 \\
\hline & Medium-low $\left(10-5<K<10^{-7}\right)$ & 5 \\
\hline & Low $\left(10-7<K<10^{-9}\right)$ & 7 \\
\hline & Impermeable $\left(\mathrm{K}<10^{-9}\right)$ & 10 \\
\hline \multirow{6}{*}{$\begin{array}{l}\text { Distance from } \\
\text { settlements (meters) }\end{array}$} & $d<500 m$ & 0 \\
\hline & $500 \mathrm{~m}<\mathrm{d}<1500 \mathrm{~m}$ & 1 \\
\hline & $1500 \mathrm{~m}<\mathrm{d}<2500 \mathrm{~m}$ & 3 \\
\hline & $2500 \mathrm{~m}<\mathrm{d}<3500 \mathrm{~m}$ & 5 \\
\hline & $3500 m<d<4500 m$ & 7 \\
\hline & $d>4500 m$ & 10 \\
\hline \multirow{5}{*}{$\begin{array}{l}\text { Average annual } \\
\text { rainfall (millimetres) }\end{array}$} & $\mathrm{P}>800 \mathrm{~mm}$ & 1 \\
\hline & $700 \mathrm{~mm}<\mathrm{P}<800 \mathrm{~mm}$ & 3 \\
\hline & $600 \mathrm{~mm}<\mathrm{P}<700 \mathrm{~mm}$ & 5 \\
\hline & $450 \mathrm{~mm}<\mathrm{P}<600 \mathrm{~mm}$ & 7 \\
\hline & $\mathrm{P}<450 \mathrm{~mm}$ & 10 \\
\hline \multirow{5}{*}{$\begin{array}{l}\text { Peak ground } \\
\text { acceleration (g) }\end{array}$} & $a>0,150 \mathrm{~g}$ & 1 \\
\hline & $0,125 \mathrm{~g}<\mathrm{a}<0,150 \mathrm{~g}$ & 3 \\
\hline & $0,100 \mathrm{~g}<\mathrm{a}<0,125 \mathrm{~g}$ & 5 \\
\hline & $0,075 \mathrm{~g}<\mathrm{a}<0,100 \mathrm{~g}$ & 7 \\
\hline & $a<0,075 g$ & 10 \\
\hline \multirow{5}{*}{$\begin{array}{l}\text { Distance from surface } \\
\text { waters (meters) }\end{array}$} & $150 m<d<300 m$ & 1 \\
\hline & $300 m<d<450 m$ & 3 \\
\hline & $450 m<d<600 m$ & 5 \\
\hline & $600 m<d<750 m$ & 7 \\
\hline & $d>750 m$ & 10 \\
\hline
\end{tabular}

\begin{tabular}{|c|c|c|}
\hline \multicolumn{3}{|l|}{ Economic criteria } \\
\hline \multirow{5}{*}{ Land slope (degree) } & $\mathrm{s}>45^{\circ}$ & 1 \\
\hline & $26,5^{\circ}<\mathrm{s}<45^{\circ}$ & 3 \\
\hline & $18,5^{\circ}<\mathrm{s}<26,5^{\circ}$ & 5 \\
\hline & $9,5^{\circ}<\mathrm{s}<18,5^{\circ}$ & 7 \\
\hline & $\mathrm{s}<9,5^{\circ}$ & 10 \\
\hline \multirow{5}{*}{$\begin{array}{l}\text { Distance from roads } \\
\text { (meters) }\end{array}$} & $d>2000 m$ & 1 \\
\hline & $1500 \mathrm{~m}<\mathrm{d}<2000 \mathrm{~m}$ & 3 \\
\hline & $1000 \mathrm{~m}<\mathrm{d}<1500 \mathrm{~m}$ & 5 \\
\hline & $500 \mathrm{~m}<\mathrm{d}<1000 \mathrm{~m}$ & 7 \\
\hline & $d<500 m$ & 10 \\
\hline \multirow{6}{*}{ Land use } & Urbanized and industrial zones & 0 \\
\hline & Permanent crops & 1 \\
\hline & Heterogeneous agricultural areas & 3 \\
\hline & Arable land & 5 \\
\hline & Pastures & 7 \\
\hline & Quarry areas & 10 \\
\hline
\end{tabular}


in the leachate production in an MSW landfill although at present this parameter is not regulated by specific legislation which imposes specific limits.

The meteorological data were provided by SIAS (Sistema Informativo Agrometeorologico Siciliano), which is equipped with a network of stations for remote measurement, consisting of 96 automatic stations that store data detected with electric-electronics instrumentation. Monthly average rainfall data (in $\mathrm{mm}$ ) refer to the 2003-2013 decade. Stations with higher values of cumulative rainfall were assigned the lowest score (Table 3 ) because they were regarded as areas of increased leachate production despite the predisposition of suitable drainage systems (Figure 4).

The peak ground acceleration criterion was taken into account using the method developed by Perricone et al. (2016) within the penalising factors, where a buffer of 300 $\mathrm{m}$ around the active faults was applied (see ITHACA catalogue, i.e ITaly HAzard from CApable faults,), excluding areas with peak ground acceleration higher or equal to 0.225 $\mathrm{g}$ of the map of the seismic hazard for Italy, realised by the Istituto Nazionale di Geofisica e Vulcanologia (INGV 2004). For the meso-scale method, it was re-applied to the areas potentially suitable already identified, considering the acceleration values less than $0.225 \mathrm{~g}$. To detect the seismic zones, we used the nationwide reference seismic hazard map mentioned above. Based on the values of the expected maximum accelerations mostly identified in Sicily, the range of values of peak ground acceleration was re-classified, dividing it into five classes (Table 3 ). The lowest score was assigned to acceleration values between 0.150 and 0.225 , while the highest score - indicative of more suitable areas - was assigned to acceleration values lower than $0.075 \mathrm{~g}$ (Figure 5).

The last environmental criterion, the distance from surface waters, according to the so-called "Legge Galasso" (L.n. 431 of $08 / 08 / 1985$ ), includes all the areas included within a buffer zone of 150 meters from the shores of rivers, streams and waterways that are subject to landscape constraints (with the prohibition of building). This criterion, already taken into account during the macro-scale method in order to exclude all those areas comprised within this range of respect, was re-analysed at this stage in order to evaluate the influence of the greater or lesser distance of a potential landfill site to a water course concerning the risk of river pollution.

To assess this criterion, five different buffer zones were created, with a spacing of $150 \mathrm{~m}$ between a band and another, around all the river courses. These bands were converted into a grid-map with a $20 \times 20 \mathrm{~m}$ resolution. To each class thus identified, we assigned a score according to the distance of the river. The maximum scores were obviously assigned to areas more distant from river shores (Figure 6).

\subsubsection{Economic criteria}

The land use criterion is not based on regulatory issues and can vary according to the study area. It is designed to protect "sensitive" areas, which are economically developing and can be negatively influenced by a landfill in their vicinity. In this paper, for the evaluation of the land use criterion, we referred to the map realised within the "CORINE Land Cover" project (updated 2012) that divides the coun- try according to the characteristics of coverage and land use, with particular emphasis on environmental protection.

Analysing the various covering features, we decided to attribute the lowest score (0) to those levels previously considered within the exclusionary and penalised factors during the macro-scale method (e.g. forested areas, urban areas, water bodies, etc.). The remaining levels were organised into five classes by giving them the corresponding score depending on the greater or lesser suitability for hosting landfill sites (Figure 7). In particular, the lowest score was given to agricultural areas characterised by permanent crops (olive groves, fruit trees, etc.), while the highest score was assigned to mining areas, including landfills and abandoned mining areas (Table 3 ).

The criterion of distance from roads or proximity to roads should be taken into account for the selection of landfill sites because it represents the greater or lesser accessibility to the site itself. In fact, landfills should be located on sites that can be reached by alternative roads even in the presence of adverse weather conditions. On the other hand, such sites should not be positioned too far from existing road networks in order to avoid excessive costs for the construction of connecting roads. In addition, transportation of waste should not interfere with normal vehicular traffic. To evaluate this parameter, we created five buffer zones around all main roads (highways, main roads, secondary and urban roads), with interdistance of $500 \mathrm{~m}$ between one band and another. These bands were converted into a grid-map with a resolution of $20 \times 20 \mathrm{~m}$ (Figure 8). To each class thus identified, a score was assigned according to the distance of the road from the landfill site, so that the maximum scores were assigned to roads closest to the potentially suitable site (Table 3 ).

The last economic criterion, the land slope or land morphology, constitutes a basic criterion for the realisation of landfill sites. In the proposed methodology, land morphology is evaluated on the basis of the slope angle, given in degrees (Table 3). Sites with excessive gradients are usually not suitable for the construction of landfills. The division into classes is based on the assumption that flat areas are most suitable for the construction of a landfill (Figure 9).

\section{RESULTS AND DISCUSSION}

According to the European waste management policy, landfilling is the least preferable option and should be limited to the necessary minimum. Where waste needs to be landfilled, it must be sent to landfills that comply with the requirements of Directive 1999/31/EC on the landfill of waste. The objective of the Directive is to prevent or reduce as far as possible negative effects on the environment, in particular on surface water, groundwater, soil, air, and on human health from the landfilling of waste by introducing stringent technical requirements for waste and landfills.

Taking into account the EU landfill directive, our Analytic Hierarchy Process (AHP) combined with Geographic Information System (GIS) allows discriminating the most suitable sites in a larger area already individuated as suitable for municipal solid waste landfill on the base of the parameters defined also by the regional requirements (Figure 1). 


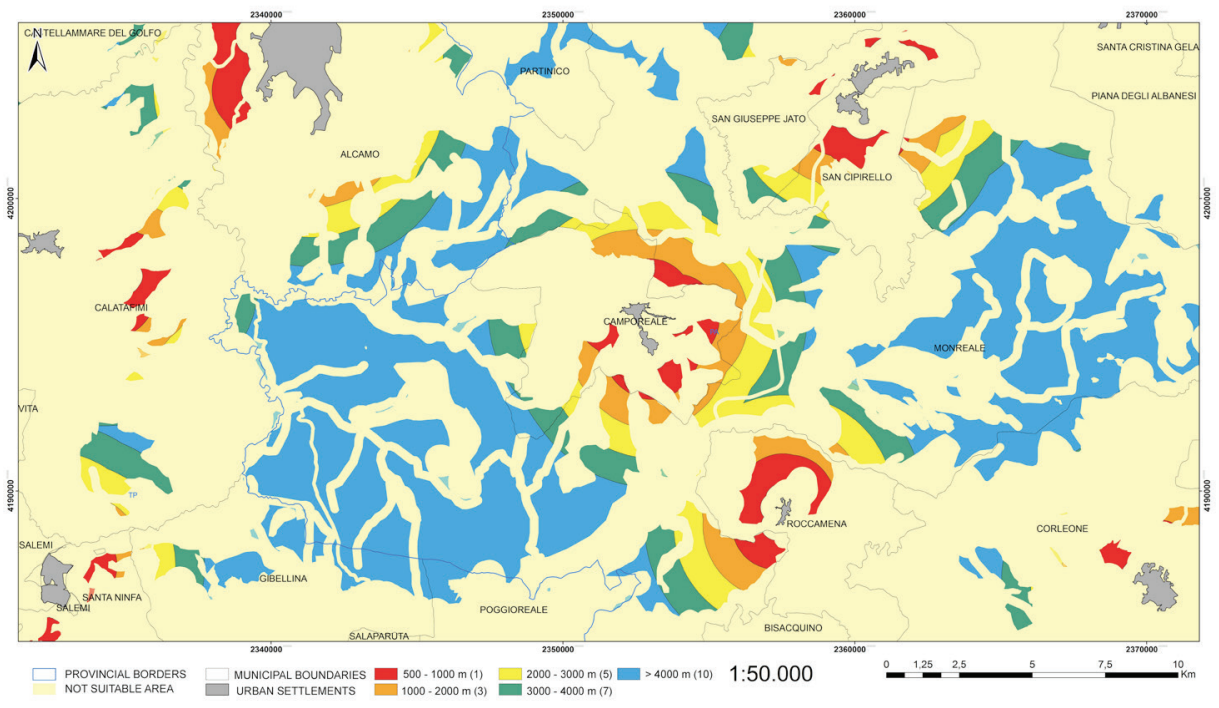

FIGURE 2: Distance from settlements criterion map for the Western sector of Sicily.

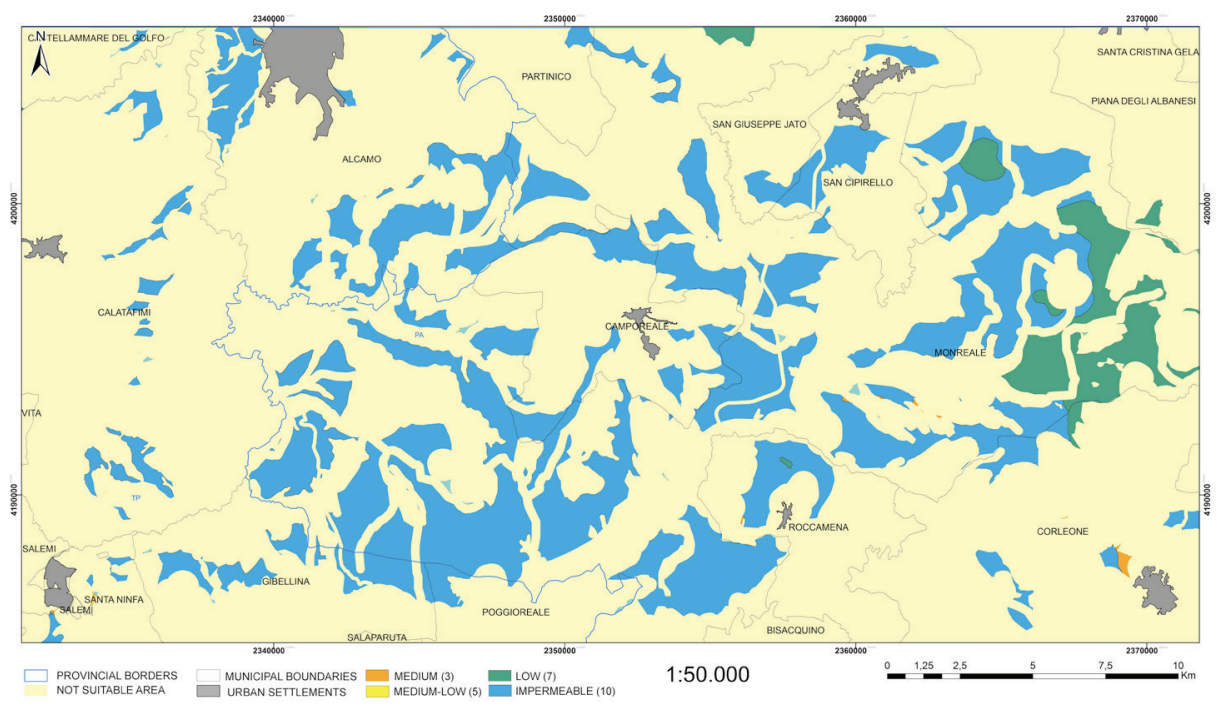

FIGURE 3: Rock permeability criterion map for the Western sector of Sicily.

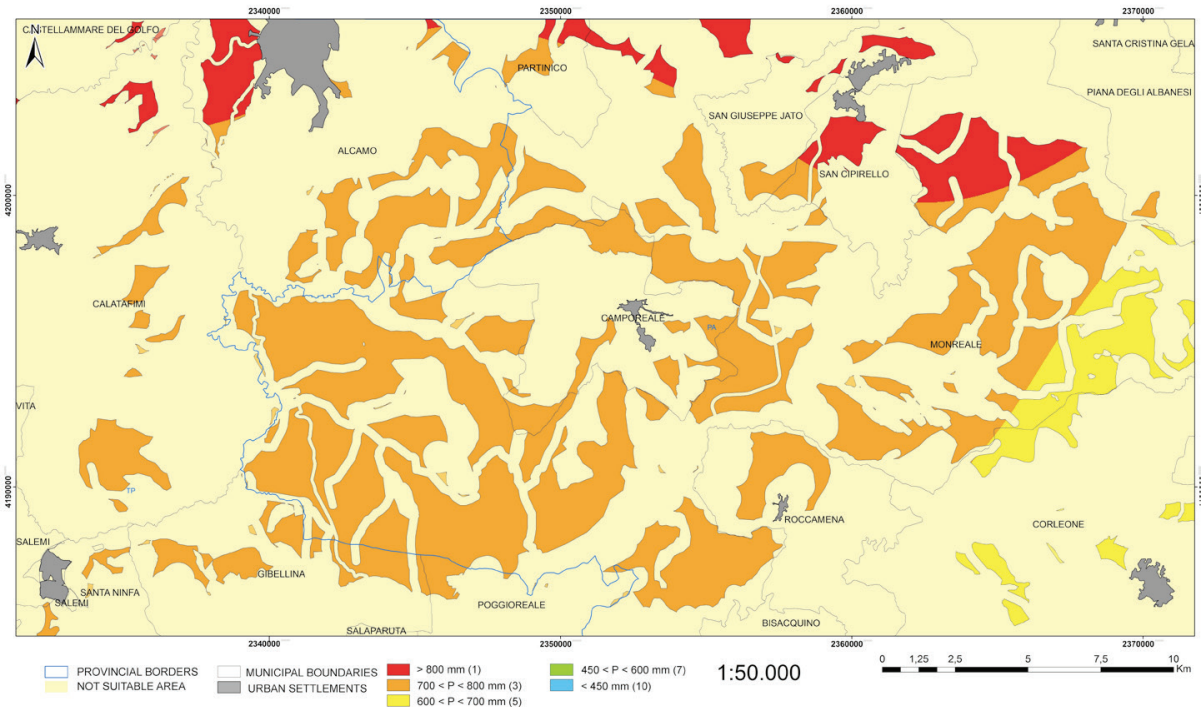

FIGURE 4: Average annual rainfall criterion map for the Western sector of Sicily. 


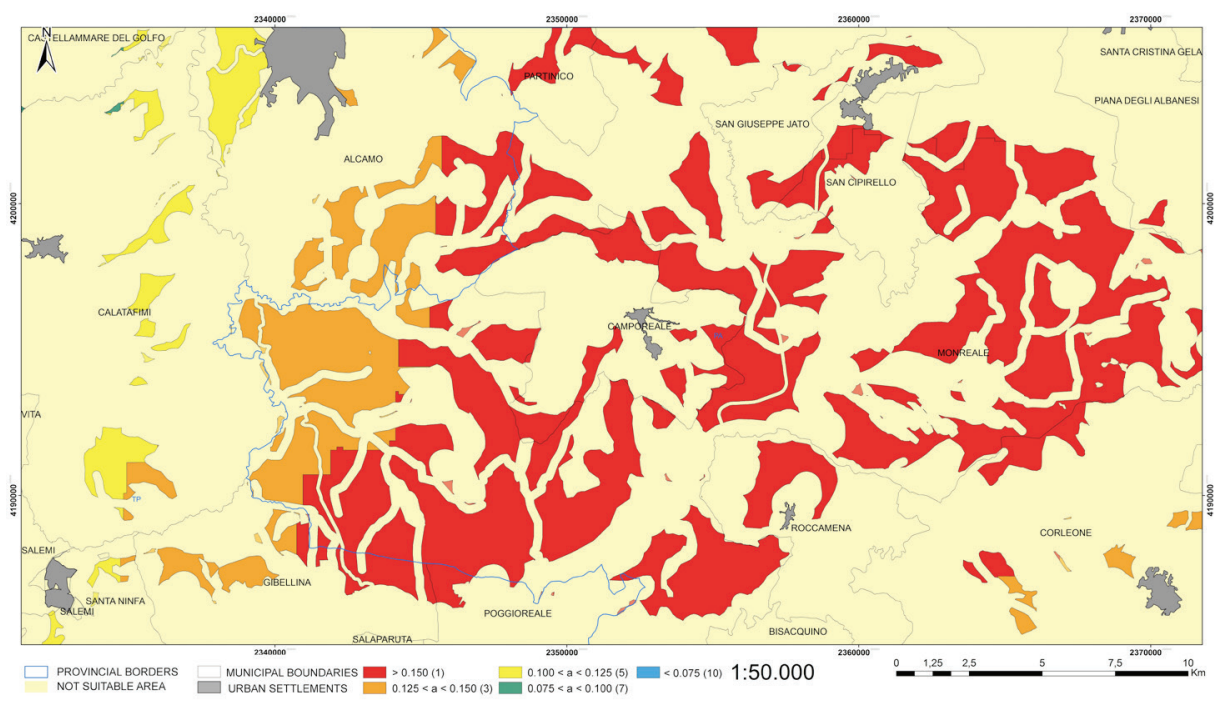

FIGURE 5: Peak acceleration ground criterion map for the Western sector of Sicily.

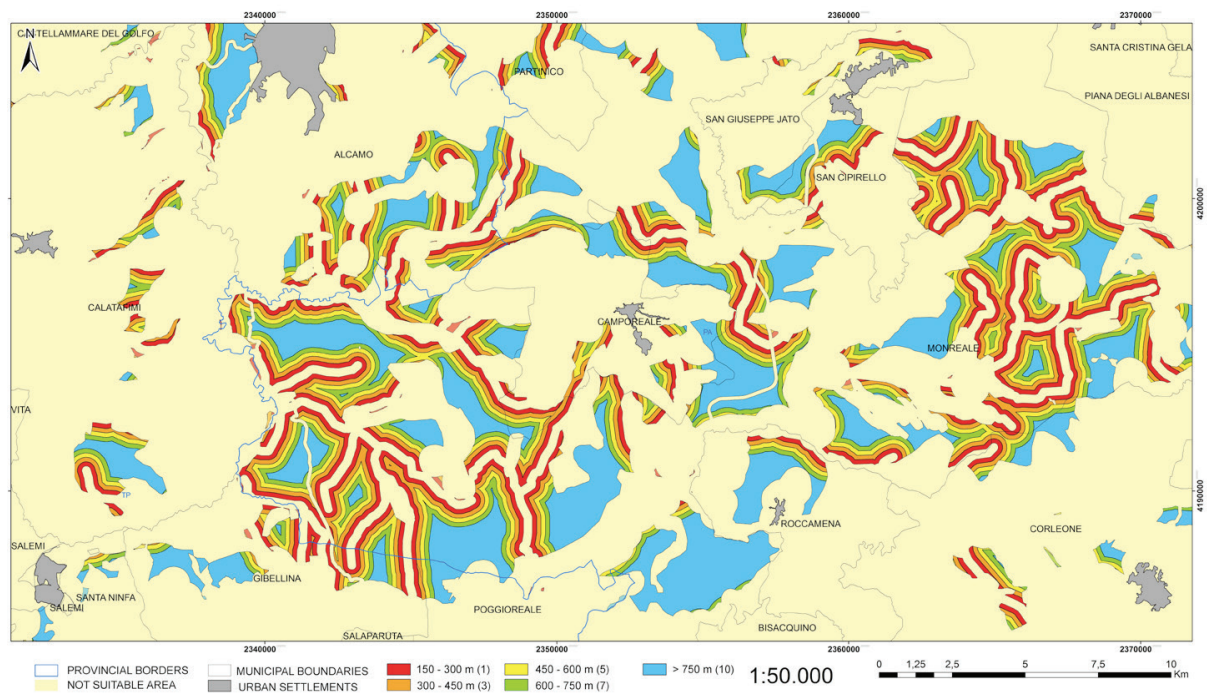

FIGURE 6: Distance from surface waters criterion map for the Western sector of Sicily.

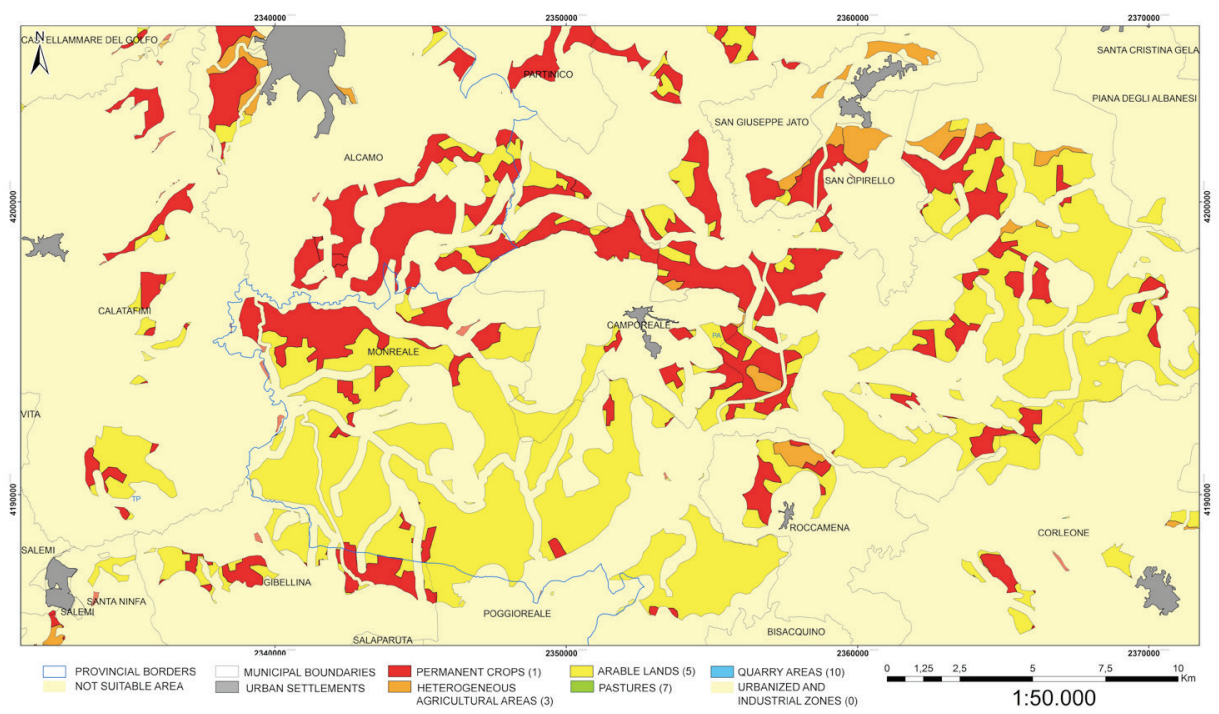

FIGURE 7: Land use criterion map for the Western sector of Sicily. 


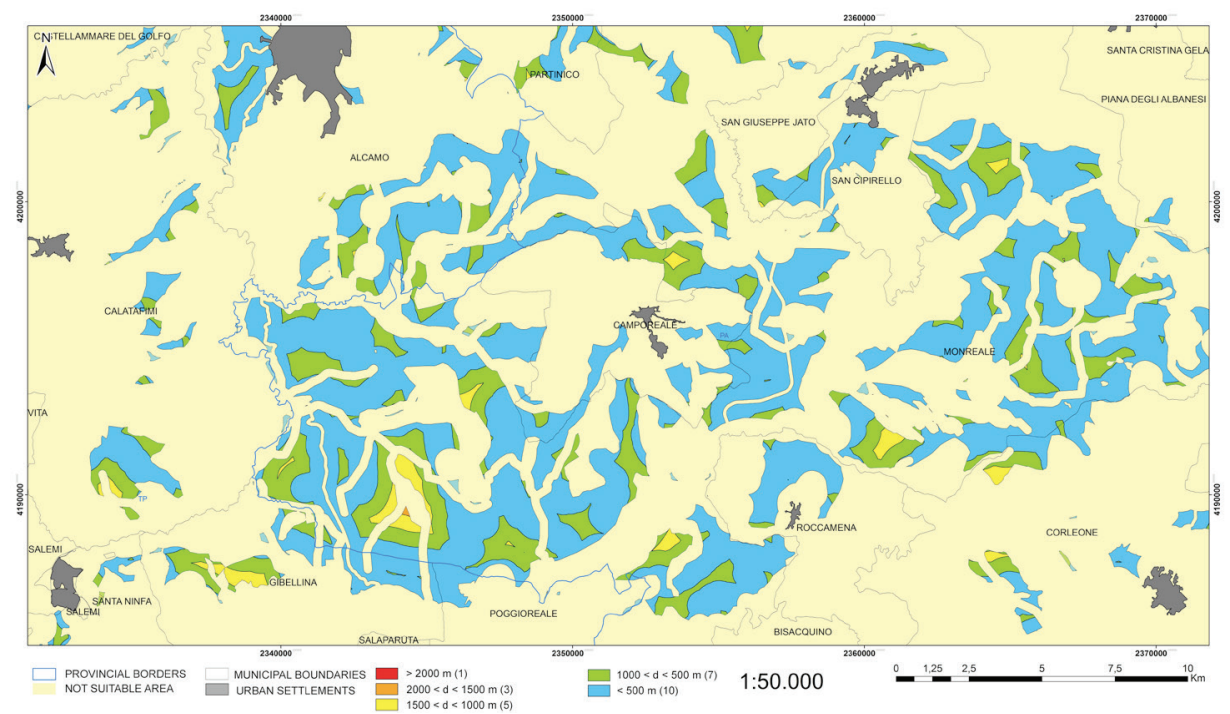

FIGURE 8: Distance from roads criterion map for the Western sector of Sicily.

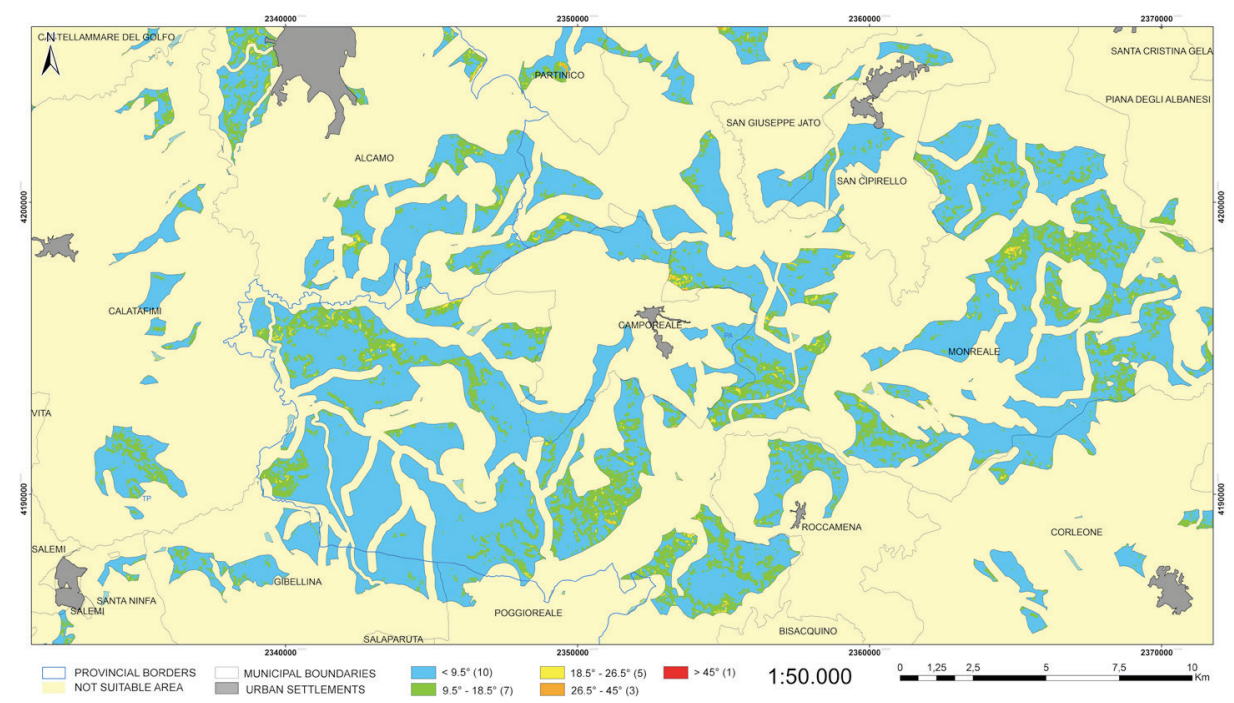

FIGURE 9: Land slope criterion map for the Western sector of Sicily.

Each criterion map was prepared using ArcGIS Spatial Analyst, and prepared maps were converted into ESRI Grid Format using weight values obtained from AHP. On the basis of the weight values assigned to each criterion, it is clear that one of the most important parameters is the permeability of the rocks ( 0.229 see Table 2$)$. This parameter has been already introduced for the selection of the larger area, however for this purpose a lithological map of Sicily in a scale 1:250.000 has been used. In this second and more detailed step the analysis of permeability was based on the lithological characters of formations and synthems reported in the 1:50.000 National geological maps recently published for the studied area (Ispra Carg project, Sheet n. 607 "Corleone" and n. 619 "Santa Margherita di Belice"). The geological substrate of the area consists of Tertiary terrigenous sediments such as open shelf marls, molasse-type clays, sandstones and conglomerates, Messinian evaporites and Plio-Quaternary sandy clays, calcarenites and al- luvial sediments. The nature and type of outcropping rocks (i.e. where highly permeable rocks crops out) has excluded large territories.

The second parameter considered equally important (0.229) was the land slope or morphology. Its importance derives both from the excessive costs of planning and construction in very steep areas and also from future problems of slope stability of the landfill itself. With regard to the remaining criteria both those associated with the presence of naturalistic-landscape constraints (for example land use) and those controlled by the Italian and EU directives (i.e. distance from surface waters), it was necessary to identify particularly large buffer areas.

Finally, the parameter of peak ground acceleration is also of particular importance because this area (more in general, a large belt running N-S across western Sicily) experienced in the 1968 a seismic sequence up to $M$ 6, which is known as the earthquake of the River Belice Val- 
ley. Several municipalities were almost totally damaged and about 300 peoples died. No clear focal mechanisms were available for this seismic sequence, so the seismicity was attributed either to the compressional reactivation of a thrust sheet or to a NW-SE shear band running from the Castellammare gulf to Sciacca (Di Stefano et al., 2015). The epicentral zones of the 1968 seismic sequence was centred southward of the studied area, thus the parameter of peak ground acceleration has to be seriously considered for the assessment of the most suitable sites.

The final suitability map was derived with the aid of the map calculator function of ArcGIS and overlay analyses of ArcGIS spatial analyst (Figure 10).

After the constrained areas were extracted by masking, the land suitability of the study area was calculated by the SAW procedure (see equation 1). By considering the determined weights, the range of the landfill suitability index was between 2.99 to 9.46 . Using an equal interval classification method, landfill suitability values of the studied area were classified into five groups: very high suitability (9.46-8.30), high suitability (8.29-7.54), moderate suitability (7.53-6.75), low suitability (6.74-5.81) and very low suitability (5.80-2.99). The results indicate that $3 \%$ of the study area has very low suitability, $26 \%$ has low suitability, $37 \%$ have moderate suitability, $26 \%$ has high suitability and $8 \%$ of the study area has high suitability for a landfill site.

Figure 11 schematically shows the used procedure by the AHP and GIS techniques in order to obtain a landfill suitability map.

In particular, four candidate sites (S1, S2, S3 and S4) were suggested for landfill use because these areas resulted as the most suitable and reach the largest ex-

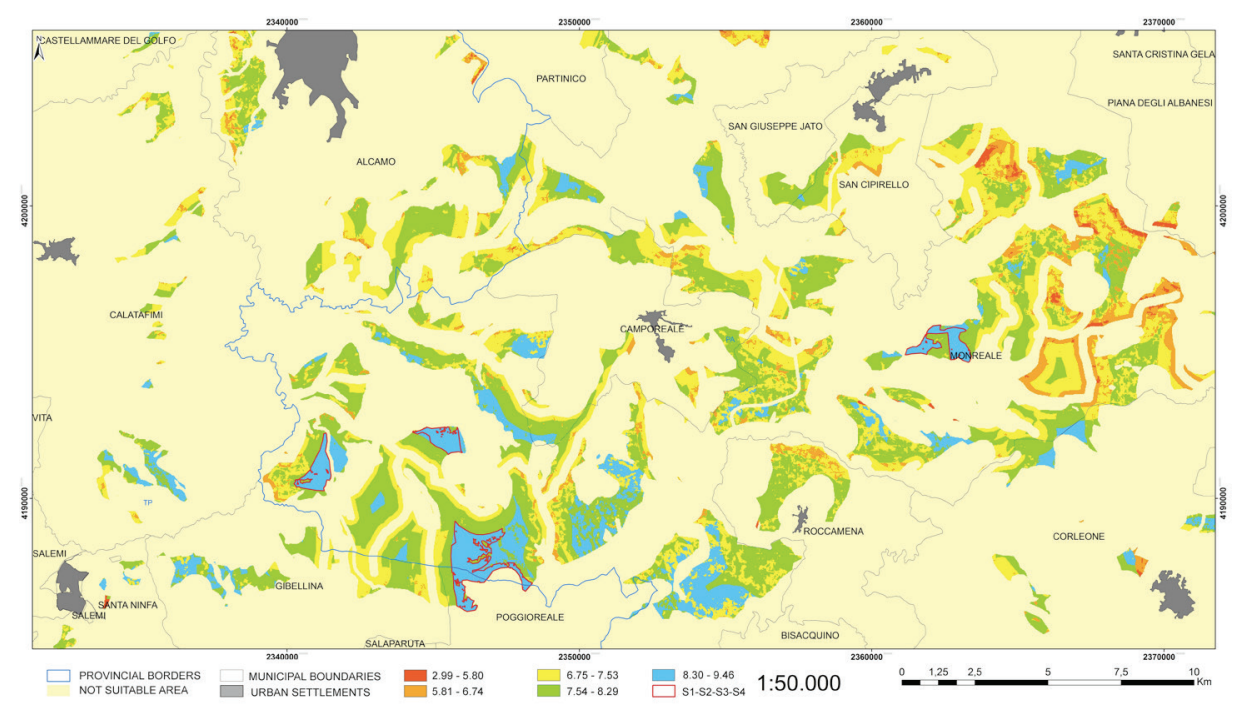

FIGURE 10: Map of the suitable area for MSW landfill locations.

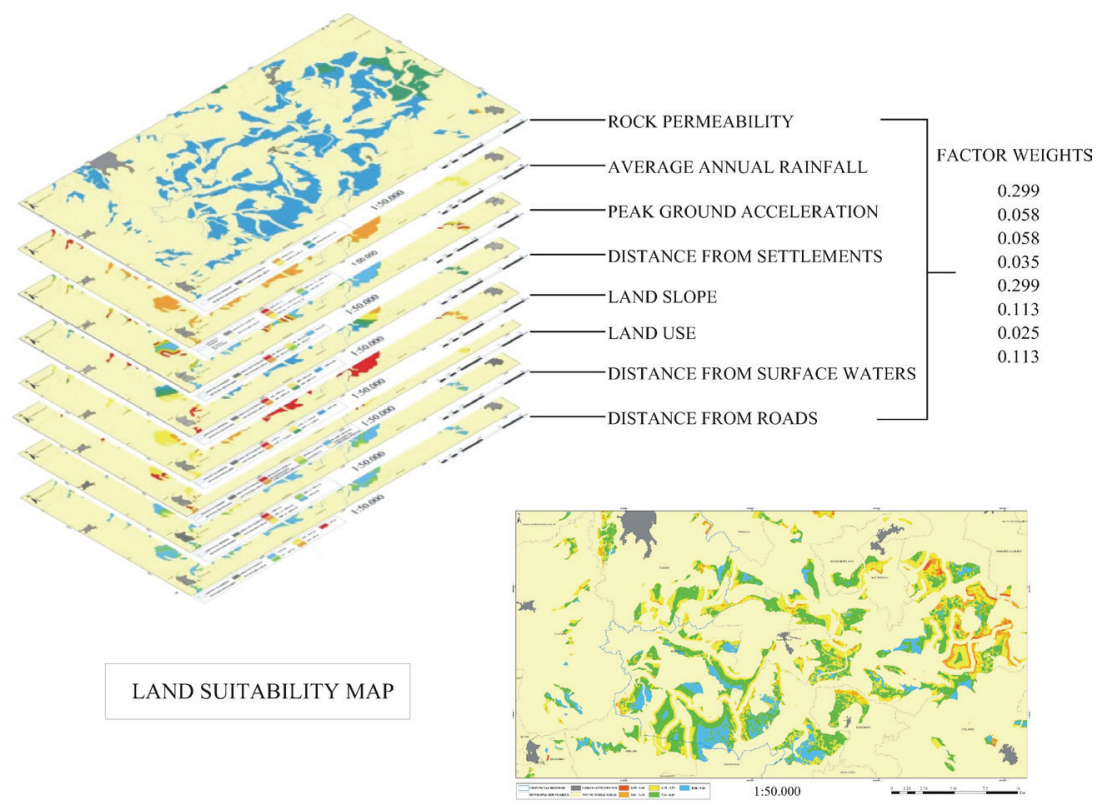

FIGURE 11: The flowchart of the methodology showing the overlay of different constrained maps and the finalland suitability map. 
tensions. After the recognition of these four areas, the comparison between them on the basis of new criteria (both economic and environmental) was carried out. For example, among the new environmental criteria, the visibility of the landfill site from urban centres or the wind direction has been considered. Results of this procedure (named the micro-scale method) will be the subject of a later work.

\section{CONCLUSIONS}

The management of municipal solid waste in Italy is currently a very topical issue. In several regions of Southern Italy, the waste emergency has become a chronic problem, especially in Sicily, where one of the main problems is the landfilling of MSW.

The presence of a landfill in a specific area involves a series of inevitable consequences that have an impact both at socio-economic and environmental levels. In these areas, depreciation of the values of properties surrounding the landfill prevails, combined with deterioration of life and air quality and increased water and soil pollution in the surrounding environment.

It is therefore extremely important to define a scientific methodology for the identification of suitable areas for the location of MSW landfills; this enables the selection of sites that constitute the minimum environmental impact and allows the local population to make sensible choices.

In this paper, we addressed the problem of identifying the areas potentially suitable for the construction of a MSW landfill for a limited area of western Sicily, using a method based on a Geographic Information System (GIS) which is already applied in Italy and abroad.

However, the application of a multi-scale localisation procedure introduced in this paper, characterised by an increasing level of analysis from the regional up to the municipal level, has allowed to detail the examined area thus providing a tool as accurate as possible in the selection of the most suitable sites among those identified.

Despite the fact that environmental and cartographic data were not updated in some cases, several areas potentially suitable to host sites for MSW landfill in western Sicily were identified.

The methodology allows the introduction of several updates, such as the choice of different parameters or the application of different multi-criteria analysis methods. The potential offered by the computer-aided procedure and GIS, allows comparisons between different suitable areas and, above all, between areas characterized by the same score. The variation, for example, of the weight values assigned to each criterion or the introduction of new criteria specifically linked to the local situation, will further facilitate the choice of the most suitable area.

The next step will be the assessment of the sites identified through the computerised procedure described in this paper, thanks to the context analyses, starting from the field survey, sampling and laboratory analysis.

In conclusion, the study carried out in western Sicily can be an instrument of knowledge useful for territorial planning which enables the identification of areas suitable to host a MSW landfill that, on one hand, protects the environment and human health and, on the other hand, respects the constraints and restrictions imposed by law.

\section{ACKNOWLEDGEMENTS}

This work was supported by the Programma Operativo Nazionale - PON R\&C 2007-2013 "Smart Cities and Communities and Social Innovation" - SIGLOD Project (D.D. Prot. n.84/Ric. del 2 marzo 2012), http://www.siglod.org/. The Authors would like to thank the anonymous reviewers for their helpful and constructive comments.

\section{REFERENCES}

Balis M, Mandylas Ch, Kontos Th, Akriotis D, Halvadakis CP (1998) Investigation of suitable areas for the construction of sanitary landfill in Lemnos. Technical Report, Part I, University of the Aegean, Department of Environmental Studies, Waste Management Laboratory/Region of the North Aegean, Mytilene, Lesvos, Greece (in Greek).

Bhushan N, Rai K (2004) Strategic Decision Making: Applying the Analytic Hierarchy Process. Springer, New York, 172 p.

Burrough PA (1986) Principles of geographical information system for land resources assessment. Clarendon Press, Oxford, 193 p.

Carone E, Sansò P (2010) Individuazione di aree idonee per la realizzazione di discariche RSU mediante tecniche GIS: esempio di applicazione in provincia di Brindisi. Geologi e Territorio, 4-2009/12010, 3-10.

Chang N, Parvathinathan G, Breeden JB (2008) Combining GIS with fuzzy multicriteria decision-making for landfill siting in a growing urban region. J Environ Manage 87: 139-153.

Colombo P, Colleselli F (2004) Elementi di Geotecnica. Ed. Zanichelli, $480 \mathrm{p}$.

Di Stefano P, Favara R, Luzio D, Renda P, Cacciatore MS, Calò M, Napoli G, Parisi L, Todaro S, Zarcone G (2015) A regional-scale discontinuity in western Sicily revealed by a multidisciplinary approach: a new piece for understanding the geodynamic puzzle of the southern Mediterranean. Tectonics 34: 1-19.

Dörhöfer G, Siebert H (1998) The search for landfill sites - requirements and implementation in Lower Saxony, Germany. Environ Geol 35: 55-65.

EU Landfill Directive (1999) Council Directive 1999/31/EC on the landfill of waste.

Gbanie SP, Tengbe PB, Momoh JS, Medo J, Kabba VTS (2013) Modelling landfill location using Geographic Information System (GIS) and Multi-Criteria Decision Analysis (MCDA): case study Bo, Southern Sierra Leone. Appl Geogr 36: 3-12.

Istituto Nazionale di Statistica ISTAT (2011) Censimento permanente della popolazione e delle abitazioni.

Istituto Nazionale di Geofisica e Vulcanologia INGV (2004) Redazione della Mappa di Pericolosità Sismica prevista dall'Ordinanza P.C.M. 3274 del 20 marzo 2003 - Rapporto conclusivo per il Dipartimento della Protezione Civile" - Gruppo di lavoro 2004, I.N.G.V.

Kontos TD, Halvadakis CP (2002) Development of a Geographic Information System (GIS) for land evaluation for landfill siting: The Case of Lemnos Island. 7th National Conference of Hellenic Cartographic Society (Expanded Abstract), Mytilene, Lesvos, Oct. 23-26, p. 98-107.

Kontos TD, Komilis DP, Halvadakis CP (2003) Siting MSW Landfills in Lesvos Island with a GIS-based methodology. Waste Manage Res 21: 262-277.

Kontos TD, Komilis DP, Halvadakis CP (2005) Siting MSW landfills with a spatial multiple criteria analysis methodology. Waste Manage 25: 818-832.

Mandylas Ch, Balis M, Kontos TD, Akriotis D, Halvadakis CP (1998) Investigation and evaluation of sites for the construction of a central sanitary landfill in Lesvos. Technical Report, Part I, University of the Aegean, Department of Environmental Studies, Waste Management Laboratory/Region of the North Aegean, Mytilene, Lesvos, Greece.

Moeinaddini M, Khorasani N, Denehkar A, Dervishsefat AA, Zienalyan M (2010) Siting MSW landfill using weighted linear combination and analytical hierarchy process (AHP) methodology in GIS environment (case study: Karaj). Waste Manage 30: 912-920. 
Nas B, Cay T, Iscan F, Berktay A (2010) Selection of MSW landfill site for Konya, Turkey using GIS and multi-criteria evaluation. Environ Monit Assess 160: 491-500.

Perricone M, Cusumano A, Oliveri G, Randazzo L, Napoli G, Zarcone G, Todaro S, Renda P, Di Stefano P (2016) GIS-Techniques and AHP method as support of decision maker in selection Landfill sites for Solid Waste. 35th International Geological Congress (Abstract), Cape Town, Aug. 27-Sept. 4, Paper Number: 1394.

Pires A, Martinho G, Chang NB (2010) Solid waste management in European countries: A review of systems analysis techniques. J Environ Manage 92: 1033-1050.

Saaty TL (1980) The Analytic Hierarchy Process. McGraw-Hill, New York, $287 \mathrm{p}$.

Sakai S, Sawell S, Chandler AJ, Eighmy T, Kosson D, Vehlow J (1996) World trends in municipal solid waste management. Waste Manage 16: $341-350$.

Seadon JK (2006) Integrated waste management-looking beyond the solid waste horizon. Waste Manage 26: 1327-1336.

Sener S, Sener E, Nas B, Karagüzel R (2010) Combining AHP with GIS for landfill site selection: a case study in the Lake Beysehir catchment area (Konya, Turkey). Waste Manage 30: 2037-2046.
Servizio Geologico d'Italia (2013) - Foglio 619 "S. Margherita di Belice" della Carta Geologica d'Italia, scala 1:50.000. ISPRA/Regione Siciliana/D.S.G.-UniPa. SystemCart, Roma.

Servizio Geologico d'Italia (2010)- Foglio 607 "Corleone" della Carta Geologica d'Italia, scala 1:50.000. ISPRA/Regione Siciliana/D.S.G.-UniPa. SystemCart, Roma.

Sharifi M, Hadidi M, Vessali E, Mosstafakhani P, Teheri K, Shahoie S, Khodamoradpour M (2009) Integrating multi-criteria decision analysis for a GIS-based hazardous waste landfill sitting in Kurdistan Province, western Iran. Waste Manage 29: 2740-2758.

Siddiqui M, Everett J, Vieux B (1996) Landfill siting using geographic information system: a demonstration. J Environ Eng 122: 515-523.

Sumathi VR, Natesan U, Sarkar C (2008) GIS-based approach for optimized siting of municipal solid waste landfill. Waste Manage 28: 2146-2160.

Yoon K, Hwang CL (1995) Multiple Attribute Decision Making: an Introduction. Sage Publication Inc., London, 83 p.

Zamorano M, Molero E, Hurtado Á, Grindlay A, Ramos Á (2008) Evaluation of a municipality landfill site in Southern Spain with GIS-aided methodology. J Hazard Mater 160: 473-481. 